\title{
Embracing Vulnerability and Risk in the Classroom: The Four- Folder Approach to Discussion-Based Community Learning
}

\author{
Elizabeth Whittenburg Ozment \\ University of Virginia \\ ewo5n@virginia.edu
}

\begin{abstract}
In recognition of various power systems within and surrounding their classrooms, U.S. women's studies instructors have for several decades worked to reconfigure the college classroom as an environment that enables all students to speak, thus creating empowered communities and ultimately inspiring the next generation of leaders. As some of the most repeated mantras of feminist pedagogy, these educational goals embody the liberating power of feminist theory and practice. The pedagogical practices employed in attaining these goals typically value experiential knowledge and encourage students to be attuned to various forms of speech and knowledge construction, which are framed through a politics of power and difference. As part of an ongoing conversation about the perils of cooperative learning, independent problem-solving, and peer leadership in higher education, this reflective essay describes one strategy, which I call the four-folder system. This instructional strategy troubles the promises of safety and implied instructor surveillance that so many feminist instructors adhere to, while simultaneously creating a multi-vocal learning environment. The techniques and rationale described may be applied to a range of courses and are not necessarily bound to introductory women's studies surveys. I propose that given favorable conditions, embracing vulnerability and risk in the classroom better frees our students from the confines of conventional pedagogies used in higher education.
\end{abstract}

Keywords: course design, safe space, peer leader, women

As feminist theory and practice continues to inspire women's instructors to value experiential knowledge and encourage students to grow attuned to the politics of power and difference, faculty often proclaim their classrooms to be "safe spaces," which refers broadly to environments where participants can express themselves freely (however provocative, painful, or personal that sharing might be) without fear of judgment or other harm. However, the assumptions underlying this socalled safety are false promises, and the rhetoric remains problematic because it primarily protects the interests of those who already possess a considerable amount of privilege in the classroom, and can aggravate existing power inequities among students, despite the instructor's intentions. As part of an ongoing conversation about risk in higher education classrooms, this article presents a strategy that embraces the inevitable perils of cooperative learning, independent problem-solving, and peer leadership. This strategy, which I call the four-folder system, resists the notions of safety and implied instructor surveillance that so many feminist instructors promise, while simultaneously creating pedagogical space in which multiple voices may respectfully exchange ideas and experiences.

The four-folder experiment responded to a particular dilemma: how do I create a democratic learning community, given the existing power inequities in my classroom? My 
response was to redesign my syllabus around a physical object: a two-pocket paper folder. Four folders strategically placed in the outer four corners of my classroom transforms a thirty-person roster into four flexible discussion groups. Inside, each folder contains activity instructions, grading rubrics, questions, answers, and memories from previous discussion sessions. Each folder is a tangible metaphor for the semester-long activity. It binds students together, is owned by the group, and is personalized with the names of each group member tattooed on the cover.

Although this essay focuses on the introductory women's studies elective, the techniques and rationale described here may be applied to courses in other departments. The article begins with a brief contextualization of the wide-spread adoption of safety rhetoric in its relation to student empowerment in feminist pedagogy, including a discussion of shortcomings, and an acknowledgment of how scholars are already addressing these issues. This background is followed by a case study drawn from my own teaching of an introductory women's studies class at a large southern research institution. The outline of my objectives, course design, and implementation of the four-folder system foregrounds how a politics of vulnerability primes students to treat weekly peer-led discussions as high-stakes exercises: students confront the risks of feminist inquiry and self-disclosure instead of hiding behind the guise of safety. I follow this section with a series of proposed lesson variations demonstrating the flexibility of the four-folder system, and reflect on how feedback from students and colleagues necessitates continual revisions in order to meet our students' needs. This essay will not directly compare or rank pedagogical tactics, but rather, introduces a method-in-progress that can potentially transform classroom spaces, sounds, and practices. I conclude that given favorable conditions such as those enabled by the four-folder system, embracing vulnerability and risk in the classroom better frees our students from the confines of conventional pedagogies used in higher education.

\section{The Logic of Safety in Feminist Pedagogy}

American feminist pedagogy evolved from the entanglement of second wave social activism and consciousness-raising groups during the 1960s, and the institutionalization of women's studies as an academic discipline in the 1970s. The women's studies university classroom emerged as a site of refuge for feminists and members of other oppressed groups who valued women's societal contributions and shared an intellectual need to probe social justice issues. Women's studies students learned how to critically read and debate cultural artifacts, and how to develop theoretical frameworks that would untangle the intricate knots of gender, race, sexuality, and other class identifiers by which we are all bound. Feminist pedagogues were first concerned with developing a vocabulary and praxis with which to discuss women's individual and collective experiences, which partly explains why these teachers were particularly receptive to students sharing personal stories (the personal is political) in the legitimization of subjectivity and the confirmation of selfknowledge (Crabtree \& Sapp, 2009; Bunch, 1983).

It was clear to feminist professors that data transmission was neither the only, nor necessarily the most important, process that occurred in the classroom. Instead, a stronger emphasis was placed on holistic student development (critical self-examination, reflexivity, and leadership), and the transformative power of language (written and verbal debate, analysis, and other forms of creative expression). Interrogating the history and politics of the American academy led many of these scholars to conclude that mainstream college curricula and classroom methods (even those at women's colleges) privileged western male history and universalized male experiences, and were not developed to benefit women (Lorde, 1984; Rich, 1979; Tisdell, 
1995). Exploring alternative models, they learned that women and other oppressed groups benefitted more from educational methods emphasizing multidimensional student development and social change instead of competition and rationality (Ibid). Feminist pedagogues drew heavily from postcolonial scholars to address classroom power imbalances, affirming prior arguments about the importance of de-centering the classroom and coaching women to trust their knowledge.

Feminist instructors experimented with methods to cultivate learning environments where all students could contribute to the imparting of knowledge. As Culley (1985) describes, "our admitted histories and contexts, when subjected to examination, can alter the form and content of how we learn and teach. Affirming that we and our students are concrete subjects of the learning process, our model becomes dialectical rather than positivistic” (p.209). Such hopes for collective educational investing led feminist pedagogues back to consciousness-raising models, what bell hooks and others envisioned as communities where women unite around honest expressions of love, anger, fear, and hope (hooks, 2003). Shrewsbury's (1987) descriptions of “democratic learning" suggested that the ideal feminist environment would be attained when "members of the class develop a community, a sense of shared purpose, a set of skills for accomplishing that purpose, and leadership skills so that teacher and student may jointly proceed on those tasks” (p.6). In Shrewsbury's vision (1987), sharing decision-making power with our students will lead to personal and community empowerment that ultimately imprints onto other domains of students' lives. Such manifestos propelled feminist teachers to reconfigure an intellectual domain that was founded on patriarchal premises.

It is understandable why safety logic, in which free speech and confidentiality are implied, became so enticing to feminist pedagogues. When professors exert every mental muscle fighting against the intellectual passivity to which women and girls have been socialized, coaching them "to occupy space... to think independently, to take intellectual risks, to assert ourselves mentally" (Rich, 1979, p.41), instructors naturally desire to nurture the ideas that students put forth, even if they are perilous to feminist principles. Here enters the dilemma of the women's studies instructor: how can we empower our students if we must safeguard them from each other? A flaw with the democratic learning model is that it assumes that the classroom operates with a flat distribution of power; that our students do not dominate each other; that they naturally respect their instructor; and that students come to the classroom wanting to be anti-sexist. But veterans of introductory women's courses know this is not always true.

In wrestling with this dilemma, Berenice Fisher (2001) questions whether safety is not actually a goal but rather a tactic that suppresses conflict in classrooms where teachers and students discuss personal experiences and feelings (p.137). Because it is assumed that all commentary is well-meant, ignorant and/or hurtful statements are too often excused by the instructor in safe classrooms (Winkler \& DiPalma, 1999). In Talking Back, bell hooks (1989) reveals the degree to which "safety" is a feminist stereotype, and argues that we should model dialogic spaces that prepare our students for the real world by empowering them to "come to voice in an atmosphere of risk" (p.53). Ideal as it may be, there are no truly safe spaces in or outside of the classroom, nor ought that be the ultimate goal for feminist pedagogues. A new goal of student accountability better aligns with bell hooks' (2014) “atmosphere of risk” and Jeannie Ludlow's (2004) “contested space" model, wherein "we know that no space is free from domination, so we examine the effects of power and privilege in our classroom environment," and redesign courses to respond to existing inequities.

Journal of the Scholarship of Teaching and Learning, Vol. 18, No. 2, June 2018. josotl.indiana.edu 


\section{A Dilemma in Introductory Women's Studies Courses}

Instructors of introductory women's studies courses find themselves in a perplexing situation: there is a constant tension between the theoretical postulations that they teach and the pedagogical methods upon which they rely. Legitimizing women's studies as an intellectually rigorous field within the academy necessitates conforming to institutional practices, which limits the possibilities for a decentralized instructional model. Restrictions to be negotiated include the semester schedule, pervasive over-valuing of quantitative assessment, even the architectural design of our classrooms challenges the egalitarian and exploratory development that women's studies theoretically champions. The sheer inevitability of assigning final grades prevents instructors from ever fully relinquishing their classroom authority, which is one of many reasons why feminist professors frequently admit that they struggle to realize the promises of feminist pedagogy (Brown, 1997). The four-folder approach does not dodge this dilemma; indeed, its very structure reflects my generous attempts to manipulate an existing framework in order to improve instruction quality.

\section{Addressing Student Needs: Foundations for the Four-Folder System}

The four-folder system arose from the specific context of a four-year period (2010-2014) during which I taught fourteen sections of a 2000-level Introductory Women's Studies course. I worked primarily with first-year students, a surprising number of whom voiced concerns about taking my class due to their presuppositions about how the field countered their conservative political and/or religious beliefs. ${ }^{1}$ Having entered into this ideologically dissonant space, I redesigned my syllabus around self-discovery and collaborative learning models that I hoped would de-escalate existing student-teacher tension and encourage students to self-examine their attitudes and values. Unlike my colleagues from the sciences whose introductory courses serve as prerequisites for qualifying exams and upper division classes, few of my students would enter into the academic or community activist field of women's studies. This freed me to tailor course content to the needs of each section. Should one class express excitement or confusion about a specific subject, I could revise the syllabus to meet that need. On the other hand, because the majority of my students would never take another women's studies course, I felt an immense pressure to cover the entire textbook anthology and expose them to as many revolutionary texts and historical figures as possible, regardless of how well they might comprehend or reconcile that literature. Confronted with the tension of these two realities, I questioned the very purpose of this class: Am I to prioritize breadth or depth, and what should be the most important learning outcome? ${ }^{2}$ Deliberate and thoughtful course planning was necessary, as were specific techniques to overcome disparities in college preparation among my students. My need to redistribute the power wielded by dominant students inspired the four-folder system to provide the structure my students needed to be successful, without sacrificing the instructional flexibility that I expect from women's studies courses.

I organized my introductory course into four equal-length thematic modules, each with a nearly-identical ordering of assignments (see fig. 1). Each week began with lectures and full-class

\footnotetext{
${ }^{1}$ All names in this article have been replaced with pseudonyms or are fictionalized composite descriptions in order to protect the identities of my students.

2 If, as Rich (1979) claims, our most important goals are empowering students with the critical thinking and problem solving skills necessary to become independent life-long learners, and if we value listening and communication skills so that our students can better assess opposing viewpoints and reach informed stances on contemporary debates, then introductory women's studies instructors ought to structure their courses around these objectives; a modified "backwards design” in the vein of L. Dee Fink (2003).
}

Journal of the Scholarship of Teaching and Learning, Vol. 18, No. 2, June 2018. josotl.indiana.edu 
instructor-led discussions that introduced theories and vocabulary related to the topic. ${ }^{3}$ Subsequent reading and other homework assignments reinforced that content, which students then applied during peer discussions when they returned to class. On discussion days, students were separated into four small teams that simultaneously discussed the readings. I followed up on these studentled discussion sessions at the end of the week, using my Friday lecture time as a full-class debriefing that contextualized their group work and pushed their analysis of the content to a more advanced stage. ${ }^{4}$ We repeated the process upon returning the next week. Assignment repetition in this modulated course design instilled a sense of security for many students, but more importantly, freed them to focus their energy on the content at hand.

\begin{tabular}{|c|c|c|c|c|c|c|}
\hline In-class & $\begin{array}{l}\text { Monday } \\
\text { Lecture } \\
\text { Introduce } \\
\text { vocabulary, } \\
\text { theories, and } \\
\text { history; } \\
\text { Model } \\
\text { analysis and } \\
\text { discussion of } \\
\text { text }\end{array}$ & & $\begin{array}{l}\text { Wednesday } \\
\text { Peer- } \\
\text { Discussion } \\
\text { Three student- } \\
\text { led team } \\
\text { discussions; } \\
\text { Full-class } \\
\text { disclosure; } \\
\text { Brief peer } \\
\text { assessment }\end{array}$ & & $\begin{array}{c}\text { Friday } \\
\text { Synthesis } \\
\text { Debriefing; } \\
\text { Guest speaker, } \\
\text { or film } \\
\text { excerpt; } \\
\text { Instructor-led } \\
\text { discussion of } \\
\text { anthology text; } \\
\text { Review }\end{array}$ & \\
\hline Out-of-class & & $\begin{array}{c}\text { Homework: } \\
\text { Read } 3 \text { assigned } \\
\text { articles from } \\
\text { anthology; Assigned } \\
\text { discussion-leaders } \\
\text { electronically submit } \\
\text { summary, discussion } \\
\text { questions, and } \\
\text { responses; Revise } \\
\text { work as needed }\end{array}$ & & $\begin{array}{c}\text { Homework: } \\
\text { Reflective journal } \\
\text { entry that relates } \\
\text { to peer- } \\
\text { discussion; Read } \\
1 \text { assigned article } \\
\text { from anthology; } \\
\text { Study as needed }\end{array}$ & & $\begin{array}{c}\text { Homework: } \\
\text { Read } 1 \text { assigned } \\
\text { article from } \\
\text { anthology; Work } \\
\text { on individual or } \\
\text { group project(s) as } \\
\text { needed }\end{array}$ \\
\hline
\end{tabular}

Figure 1. Weekly class structure. "Castle top” graph design borrowed from Fink (2003).

\section{Doubts and Decrees}

"My instructor always did a good job of listening to our opinions, even when they differed from the ones she had. Everyone also had a chance to speak and every single person was always treated with the same respect and appreciation; this is something that is not present in many classes I have taken before.” - end-of-semester student reflection.

Women's studies instructors typically establish a set of guidelines to regulate student behavior before class discussions. But the manner of creating these rules can be more important than the resulting laws, and in relation to the four-folder system, this stage marked an important first step in the decentering process. My classes read a series of articles about the purpose of a

\footnotetext{
${ }^{3}$ This orientation provides students with tools for success that they may implement during independent discussions. In addition to a theoretical introduction, I also cover leadership and conflict management strategies. See Warren (2000) and Weber Cannon (1990).

${ }^{4}$ I have conducted the four-folder method with classes that meet two or three times per week and found that it worked equally well with either format. For simplicity, this article only describes the implementation for a class that meets three days per week.
}

Journal of the Scholarship of Teaching and Learning, Vol. 18, No. 2, June 2018.

josotl.indiana.edu 
women's studies education, then discussed the lingering need for women's studies on college campuses and the challenges that these courses pose. To a certain degree, my students already knew the classroom to be a risky place, and I used this pre-knowledge as the basis for an activity that I called "Doubts and Decrees." Students were first asked to create a "doubts" idea map that predicted potential hazards of women's studies-themed student-led discussions. These idea maps generally highlighted the following fears:

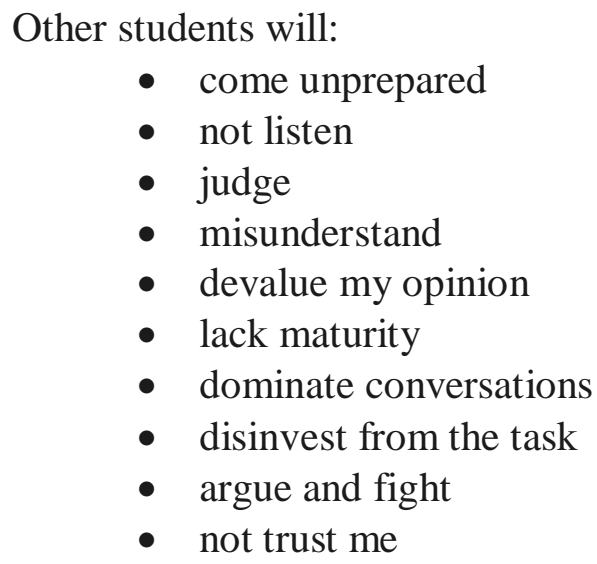

Students rarely disagreed with the items on this list because they recalled these fears from prior class experiences (which is how this activity primes students to trust the subjective truths of their peers). Usually absent from these lists were accounts of race, class, gender, sexuality, etc., that were likely to be at the crux of discussion disputes, so I seized upon this as an opportunity to shift the class' attention to these unspoken power systems. "Why do these problems manifest?" I ask, which serves the basis for a second "decrees" idea map of strategies to confront said doubts. Perhaps unsurprisingly, students across all sections of my introductory classes arrived at similar decrees, which included some combination of the following items:

All students must:

- come prepared

- listen closely

- engage in dialogue

- ask questions

- be encouraging

- not interrupt

- be mature

- refrain from slurs, stereotypes, and intentionally hurtful remarks

- not force the disclosure of personal information

- hold each other accountable for our words

- seek a deeper understanding of the subject

- remain focused on women

\footnotetext{
${ }^{5}$ This activity was inspired by Weber Cannon (1990) and Ludlow (2004). Unlike Ludlow's instructor-mandated list, my interpretation of the assignment is student-driven. And unlike Weber Cannon's ground rules, it is anticipated that my students will not always follow the rules generated by their idea maps.

Journal of the Scholarship of Teaching and Learning, Vol. 18, No. 2, June 2018.

josotl.indiana.edu
} 
The doubts and decrees activity frames peer discussions as an environment with easily identifiable risks. My students invariably replicated rules advocated by proponents of "safe" women's studies classrooms, but such lists fall short of challenging power disparities that make peer discussions unsafe undertakings for students who inhabit marginalized identities.

To their lists I added a simplified version of Weber Canon's (1990) discussion ground rule: "acknowledge the existence of sexism, racism, heterosexism, elitism, ageism, ableism, and eurocentrism, however differently we each experience these systemic and institutionalized systems of power," (p.126) in order to remind us all of the governing structures that be. But this is a tall order, so I clued students to be mindful of how power and privilege often manifest in peer discussions. I warned my classes about feeling-based statements such as "I believe" that often lead students to interpret opposing beliefs or critiques as personal attacks. I advised students to be mindful of how we embed our race, class, gender, sexual, ethnic, religious, generational, national, etc. identities in explanatory "I" and accusatory "You" possessive pronouns. My predictions reinforced a common theme about how our perception and reactions stem from our identities and social positions. I then segued to my own set of discussion rules, a two-stage discussion progression that guides students from concrete to more abstract information. ${ }^{6}$

- Stage 1: Students are first required to reach a consensus about the author's stance (who is she, what is she saying, what is the context, and why is this important in the context of our class?) before;

- Stage 2: Engage with each other's interpretations (I think), judgments (I do/don't agree) and life stories (when I), as a means to connect new knowledge to their own prior knowledge and experiences.

I bound their doubts and decrees inside discussion folders (later described in detail) as a reminder to expect conflict as well as accountability in each stage, and to realize that not all ideas have a proper place during our discussions. ${ }^{7}$ These decrees were inevitably broken, but despite growing evidence that discussion rules are ineffective at regulating student behavior (Sensoy \& DiAngelo, 2014; Ludlow, 2004), the very act of creating them was an important developmental step towards self-governance. The rules existed to draw attention to problems, not solve them.

\section{Strategic Separation}

"I am shy, so being able to speak out to only a handful of people was very helpful to me and allowed me to participate comfortably, so it helped me to understand the concepts that we were learning." - end-of-semester student reflection.

Within classrooms we each navigate shifting positions of power relative to the subjects who surround us. Given that it is impossible to eliminate the social politics at play (Ludlow, 2004; Johnson-Bailey \& Lee, 2005), the best outcome is to avoid exaggerating existing problems. Before I assigned students to discussion groups, I closely studied their personalities and social interactions

\footnotetext{
${ }^{6}$ Groups are welcome to remain in stage one, which does not imply a less meaningful discussion.

7 These rules clarify that students will be accountable for the content and framing of their ideas. The objective is not to silence individuals, but to task them to recognize how ideas are rooted in race, class, gender, ideologies. See Applebaum (2014), and Sensoy \& DiAngelo (2014).
}

Journal of the Scholarship of Teaching and Learning, Vol. 18, No. 2, June 2018.

josotl.indiana.edu 
in class and through a series of written assignments in which they reflected on their biographies. Strategic separation of students presented opportunities to negotiate power disparities.

I was particularly aware of the placement of minority students who are less likely to feel comfortable in the women's studies classroom in the first place (hooks, 1989) and are more likely to be negatively impacted by instructional activities that emphasize risk. It is not enough to rely on university admissions offices to ensure that our campuses are diverse and inclusive, so faculty must be mindful of situated power and difference when they evaluate and manage their students. Because my classes at this institution were $75 \%-80 \%$ white, I assigned multiple students of color to discussion groups as an attempt to reduce the perceived pressure for these students to act as racial ambassadors or feel obligated to conform to the perspectives of their white peers. Regarding other visible identifiers, I have yet to encounter a women's studies class with more than $10 \%$ male students at this institution, which led me to carefully spread out male students and domineering students so that they did not pool their privilege. ${ }^{8}$ Depending on enrollment, each class resulted in four discussion groups of six to eight students.

"I really enjoyed how we had class discussions with small groups. I felt like that allowed me to be much more verbal because you didn't have to say it in front of the entire class. I think I am not only am more aware of women's issues and the way our society works but I also think I'm way better now at reading something and thinking." - end-of-semester student reflection.

The type of temporary and flexible strategic separation described here links a diversity initiative to course learning objectives, but it does not make the classroom safe. ${ }^{9}$ On the contrary, my insistence on diverse discussion groups during four-folder activities increased the likelihood of dissonance and misunderstanding. Risks and accompanying student discomfort from voicing and listening to competing interpretations and life experiences facilitated active learning when students assumed the responsibility of engaging each other, and students recognized improvements in their own discussion skills. One student shared:

"I speak better in public and voice my opinion more. Learned to listen to what others have to say and digest other people's opinions. Very interesting topics. Great environment for discussion." - end-of-semester student reflection.

Gratifying long-term effects from this discussion strategy included increases in my students' ability to engage in difficult conversations that required reading comprehension, listening, and analyzing arguments by their authors, their peers, and themselves.

"Having the same group all year helped us grow together and we were constantly becoming more comfortable working with each other which allowed for better discussions. The articles chosen were also interesting and showed me a different point of view on a lot of things and gave suggestions on how we can combat certain issues." - end-of-semester student reflection.

\footnotetext{
${ }^{8}$ The impact of male students in women's studies classes extends beyond the scope of this paper.

${ }^{9}$ My use of the term "minority students" refers primarily to students of color, but my data collection and strategic separation heightened my attention to the placement of adult learners, LGBTQ-identifying individuals, students with disabilities, international students, and students who identify as working-class.
}

Journal of the Scholarship of Teaching and Learning, Vol. 18, No. 2, June 2018. josotl.indiana.edu 
These academic skills were visible and audible, as the students who once retreated or silenced themselves in the face of conflict grew increasingly accustomed to remaining in the conversation, and those who once snapped back at the mere suspicion of dissent usually found methods of self-restraint. Peer discussions initially sounded like conversational waves that built and crashed into periods of awkward silence, but gradually developed into blocks of loud constant sound.

\section{Student Responsibilities}

"I thoroughly enjoyed meeting with my group because we worked very well together. It made it much easier for me to share my own thoughts because the small size was less intimidating than the class as a whole. Creating our own discussion questions helped me focus on the text and also helped me learn the information more effectively." - end-ofsemester student reflection.

Additional structuring of the peer-discussion experience was critical to promote feelings of interdependence and liability for each other's success (Johnson, Johnson, \& Smith, 1991). Before each weekly peer-discussion, the entire class read three short articles from the textbook anthology. These articles were excerpts from milestones in twentieth-century feminist literature that ranged in length from a three-lined poem to five pages of autobiographical criticism. For each of the assigned articles (see table 1), one student from each discussion group assumed a leadership role. ${ }^{10}$ The selection and ordering of reading assignments was not random, as not all texts do a good peer-discussion make. Likewise, given the social/political environment where I taught, I never assigned texts on peer-discussion days that covered abortion, domestic violence, or rape survival stories, all subjects which I saved for myself to moderate. ${ }^{11}$

\section{Table 1. Discussion leader assignments}

\begin{tabular}{|c|c|c|c|c|c|}
\hline Date & Article Title & Group 1 & Group 2 & Group 3 & Group 4 \\
\hline \multirow{3}{*}{$\begin{array}{l}\text { Oct } \\
14\end{array}$} & Higginbotham, “Teen Mags” & Hillary B. & Zach M. & Sarah C. & Tanya $\mathrm{O}$. \\
\hline & Zuniga, "Gender in the Media” & $\begin{array}{l}\text { Bernice } \\
\text { P. }\end{array}$ & Alice F. & Lauren R. & Liz E. \\
\hline & Pozner, "What TV Teaches" & Emma K. & Lori G. & Rehwa F. & $\begin{array}{l}\text { Marsha } \\
\text { T. }\end{array}$ \\
\hline \multirow[t]{3}{*}{$\begin{array}{l}\text { Oct } \\
21\end{array}$} & Chernik, "The Body Politic” & Elena Z. & $\begin{array}{l}\text { Madison } \\
\text { R. }\end{array}$ & Paula W. & Ashley B. \\
\hline & Rodriguez, "Breaking the Model” & Yen $\mathrm{O}$. & Renee S. & $\begin{array}{l}\text { Hannah } \\
\text { Q. }\end{array}$ & Hisaye C. \\
\hline & Siebecker, "Fat Girl Rules” & Irina V. & Julie C. & Yawen S. & John W. \\
\hline $\begin{array}{l}\text { Oct } \\
28\end{array}$ & $\begin{array}{l}\text { Mainardi, "Politics of } \\
\text { Housework' }\end{array}$ & Hillary B. & Zach M. & Sarah C. & Tanya O. \\
\hline
\end{tabular}

\footnotetext{
${ }^{10}$ In a group with six students, each student leads a discussion every other week.

${ }^{11}$ Regarding the criteria for what risk is appropriate for small groups, this ethical decision is best made by the instructor and based, in part, on their knowledge of the socio-political climate of their campus. For information about student re-victimization, see Amy (2006).
}

Journal of the Scholarship of Teaching and Learning, Vol. 18, No. 2, June 2018.

josotl.indiana.edu 


\begin{tabular}{|l|l|l|l|l|l|}
\hline & $\begin{array}{l}\text { Crittenden, "Price of } \\
\text { Motherhood” }\end{array}$ & $\begin{array}{l}\text { Bernice } \\
\text { P. }\end{array}$ & Alice F. & Lauren R. & Liz E. \\
\cline { 2 - 5 } & Ehrenreich, "Nannies, Maids” & Emma K. & Lori G. & Rehwa F. & $\begin{array}{l}\text { Marsha } \\
\text { T. }\end{array}$ \\
\hline
\end{tabular}

Peer discussion leaders completed a substantial amount of preparatory homework related to their assigned article, including electronic submission of the following items at least twentyfour hours in advance of the discussion period:

a) a one- to two-page response paper that identified the thesis, summarized the content, and related the text to previous reading assignments

b) a one sentence article summary to be read aloud at the start of their discussion session

c) six discussion questions that check for reading comprehension and recall, analysis, and knowledge integration.

d) answers to each discussion question in extended prose.

This preparatory assignment allows for individualized feedback regarding comprehension, analysis, and writing quality, but more importantly, it enables pre-class interventions in the case of inappropriate questions, and aids the instructor's preparation for the pending group activity. ${ }^{12}$

\section{Implementing the Four-Folder System}

On discussion days, students entered and immediately moved to their designated discussion group area where I placed their team's two-pocket folder (see fig. 2). Inside, students found graded work from the previous week, a semester-long list of peer leader date/text assignments, a collection of peer-evaluation materials, a copy of their doubts and decrees, and a pocket for submission of new work to be graded. My students came to class prepared to perform three consecutive discussion periods, each of which varied in length from ten to fifteen minutes, depending on the depth and difficulty of the text (see fig. 3). Each peer-discussion period was measured by a timer at the front of the room. Upon hearing the "ding," a neatly choreographed flipping of textbook pages visibly marked the beginning of their discussion work. It was during this opening sequence that I took my place to the side of one discussion circle and observed the conversation. Discussion leaders were required to read their one-sentence article summary aloud and then delve into a sequence of textbased questions that they crafted as homework. Although I coached students to refrain from making pop-culture references or soliciting the disclosure of personal stories, by no means did this prevent either topic from entering the discussion. Peer discussions tended to meander with multiple idea strands overlapping and spiraling around each other until the conversation converged around a truly deep or controversial idea. The following description does not describe an event from any one section of my introductory women's studies classes, but is instead a fictionalized composite description that captures the essence of student discussions that arose from my implementation of the four-folder system. ${ }^{\mathbf{1 3}}$ In this scene, the discussion leader poses a question that leads her peers into a multi-pronged conversation about an excerpt from Betty Friedan's The Feminine Mystique (1963).

\footnotetext{
${ }^{12}$ On the rare occasion when fewer than twenty students enroll, I assign a weekly précis in response to each article. This assessment strategy may prove unrealistic for instructors facing larger classes or heavy teaching loads.

${ }^{13}$ Fictionalizing protects the identities of my students and captures the repetitiveness of similar conversations across many sections of my women's studies class.
}

Journal of the Scholarship of Teaching and Learning, Vol. 18, No. 2, June 2018.

josotl.indiana.edu 
Laura (discussion leader): "What does Betty Friedan mean when she says the problem has no name?"

Agnes: "So there were all of these women that were feeling the same emptiness in their lives but no one was talking about it, and they didn't realize that it was a shared problem."

Beatrice: "Yeah, I agree. Because there was nothing to call it, it prevented them from discussing it with each other. It made each of them feel like it was their fault, and that made them feel crazy."

Caroline: "That's why I didn't understand this article. We are sitting here and talking about it with each other, and there's still no name for it, right? I mean, Friedan never gave it a name. I didn't like the women in this article because I just don't understand how these women put up with this. They're so passive. There was this one woman in the article that was practically suicidal, and her solution was to basically sleep all day until she died."

Agnes: "It's like that Leonardo DiCaprio movie, Revolutionary Road.

Danielle: "Or the Stepford Wives."

Beatrice: “That's how all problems start. There didn't used to be a term for sexual harassment either. That phrase did not exist. So many women were experiencing it but there was no outlet for them because how do you report something for which there is no word? It makes me think of that Anita Hill testimony we read."

Agnes: "My mom was a stay at home mom when we were growing up. I hope she never felt this way. I mean, she always seemed happy to me.”

Beatrice: "Did you ever ask her if she was happy, or if being a housewife was what she wanted to be?"

Agnes: "No. I mean, I don’t think she would have told us kids anyway. I mean she went to college and worked and stuff before she had us, so she chose to be a stay at home mom. We're all grown and she still hasn’t gone back to work.”

Laura: "So that relates to my next question. All of the articles that we read this week seem to be about the availability of life choices. The women in this article all went to college, and yet it seemed inevitable that they marry and become housewives. How much choice did these women have, and to what degree has this scenario changed?”

Although fictionalized, this excerpt captures numerous instances of critical thinking and collaborative learning within a short time span, and already we can begin to identify which students understood the article and those that could link the knowledge more broadly to our class and the real world. The discussion leader crafted questions that drew attention to the author's thesis without decoding the text for her peers. Agnes was able to answer the discussion leader's question and also chose to disclose a personal connection she made to the text by relating it to her mother, thereby relating the past to the present. Caroline was still processing the text, but was able to point to specific issues she had and talk through them. And what seemed at first to be an admittance of miscomprehension developed into a legitimate critique. The pop-culture references that followed her statement may seem to veer off topic, but I have found that comments like these are an attempt by her peers to engage and support the vulnerability and critical interpretation she displayed when she admitted to not identifying with the characters in the text. Beatrice assumed the role of peer- 
teacher by relating the text to other course materials, which helped pull the other students back on topic. She also demonstrated (in her response to Agnes) how students frequently latch onto disclosure statements as a point of entry into more complex questions. For the assessor, this excerpt also draws attention to Danielle, who was not able or willing to fully engage the question posed by the discussion leader. I would re-evaluate Danielle's contribution when I later returned for additional observations of this group.

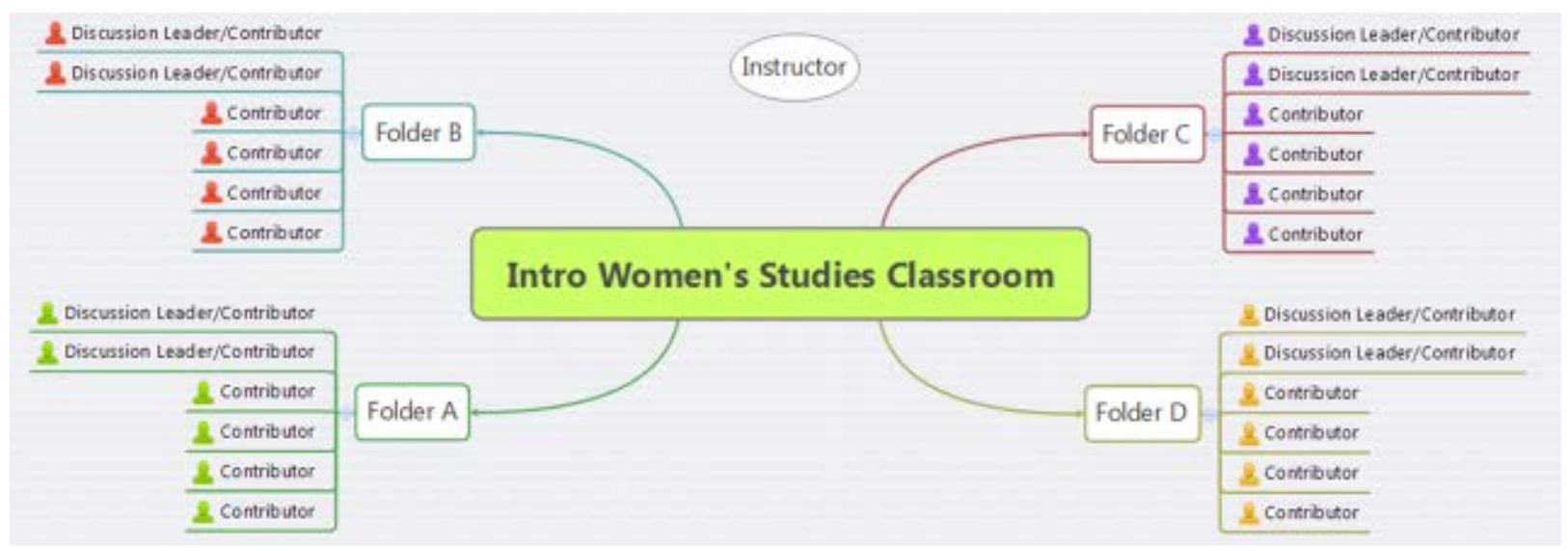

Figure 2. Standard four-folder classroom organization with floating instructor.

As the discussion period progressed, I rotated between groups, briefly visiting each corner of the classroom (see fig. 2). This process repeated when the second and third discussion leader from each group shifted the conversation to the next article. I brought closure to their conversations through a full-class overview during which I recapped the most significant discussion moments I had observed and reflected on the commonalities across each discussion group (see fig. 3). Rejoining the class for this reflective debriefing was a significant step towards building a learning community.

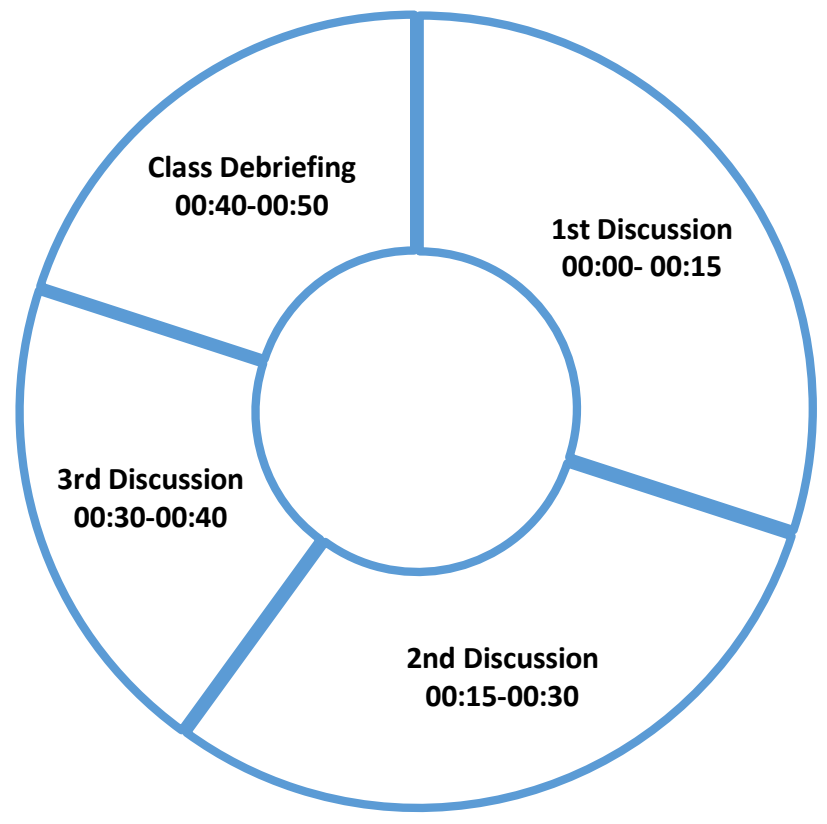

Journal of the Scholarship of Teaching and Learning, Vol. 18, No. 2, June 2018.

josotl.indiana.edu 


\section{Figure 3. Division of peer discussion time.}

\section{Variations on a Theme}

Should the descriptions of the four-folder system thus far seem stiff and repetitive, I offer the following variations that may operate as a virtual reset-button to re-energize the class, disrupt undesirable behaviors, and diversify interpersonal contact:

Pinwheel method. The discussion groups located in the four corners of the classroom are split, with half of each group breaking apart to join a group in another corner. To quickly and efficiently effect this transition, I asked all of the contributors (i.e., those students who are not leading a discussion) to move clockwise until they reached a new discussion leader. This repeated after each discussion session, and created a pinwheel-like experience that permitted discussion leaders to interact with a more diverse group of respondents (see fig. 4).

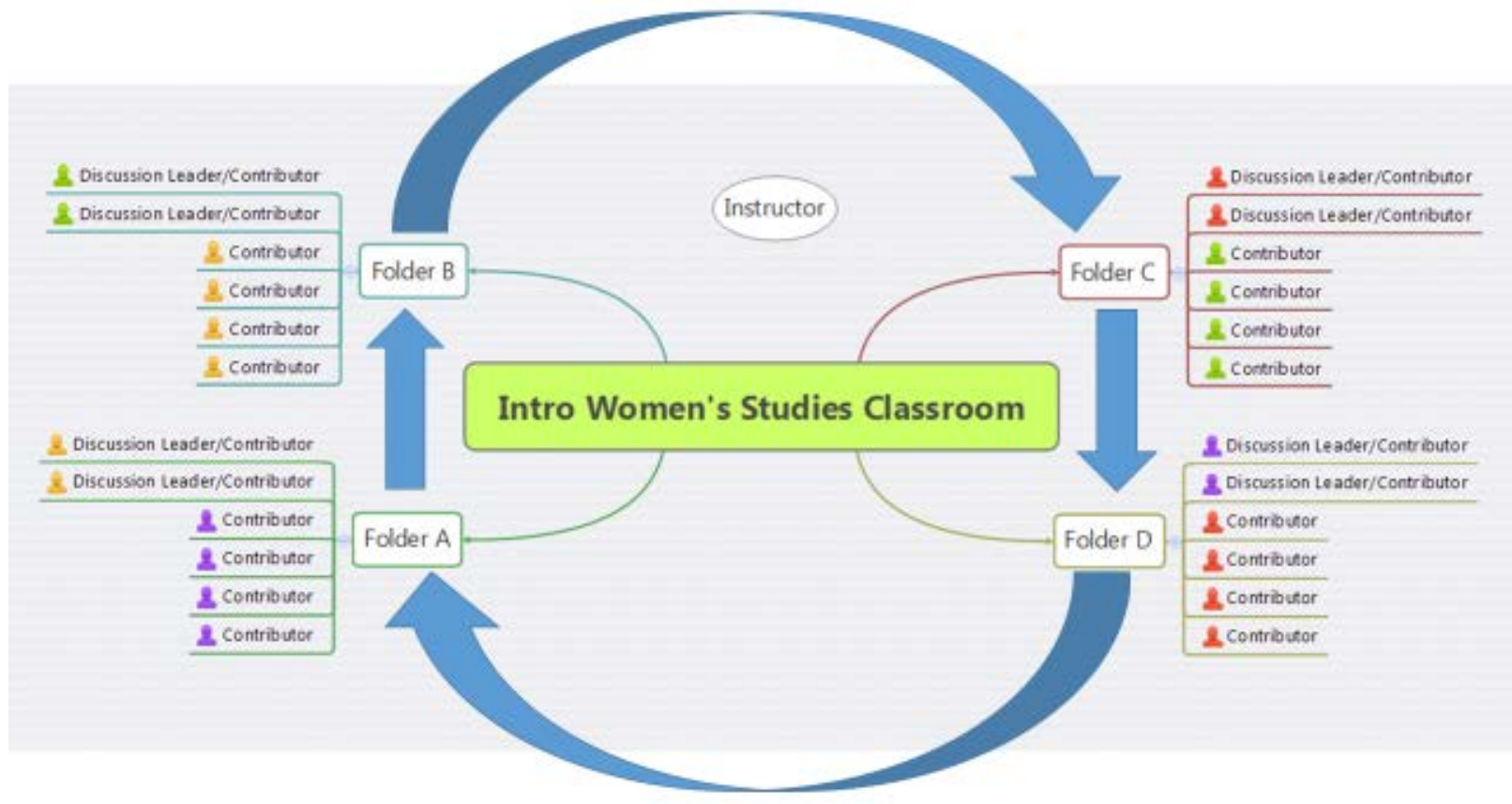

Figure 4. Pinwheel variation with rotating discussion contributors.

Scatter method. Index cards, each with a student's name across the front, are taped to the classroom walls before class to create new groupings of students. At any moment, I can pause the discussion and relocate students to new groups by moving their index cards; not a word is required on my part. This strategy is useful for regrouping the class into stronger/weaker groups, particularly if certain students would benefit from individualized coaching sessions with myself while the rest of the class continues independently.

Panel method. For potentially volatile discussions, I rely on the panel method for the greatest amount of classroom surveillance. I place tables, chairs, and name cards at the front of the room and sit the group discussion leaders there. Having already previewed their questions, I compile and order their best questions, then act as the panel moderator, calling on the student panel to ask those questions to the whole class. This method is particularly useful for reenacting discussions from previous weeks, if there is a topic that the class needs to revisit. 
Roll call method. In this variation, discussion leaders are asked to direct each of their questions to a different student by calling out the chosen student's name before posing the question. After the chosen student answers the initial question, the discussion leader then selects another student to respond to the presented answer, and the discussion proceeds in this manner. When there is a consistent imbalance in the amount of student engagement, or a recurring problem with students interrupting each other, this method helps control the order and frequency of speakers.

Post-board method. The end of class does not necessarily signal the end of the discussion. If a topic is particularly exciting or challenging to a class, or if time runs out before the topic is adequately covered, the instructor may move the discussion to an online discussion board on a secured class homepage where the conversation may be opened up to the entire class. In my experience, international and recently-immigrated students who are self-conscious about their English vocabulary and/or accents were most enthusiastic about the post-board method.

\section{Student Assessment}

Four types of weekly interlocking formative and summative assessments determine a significant portion of students' final grades. One quarter of their final grade is determined by averaging their discussion leader grades, and their discussion contributor performance constitutes another quarter. While a student's role as contributor may at first glance seem secondary to the four-folder system, it is in this position that the instructor is most likely to observe evidence of students' metacognition and self-reflection as they spontaneously compare/relate their understanding of the text and their experiences to the knowledge-producing students around them. Equal weighting of these two roles emphasizes interdependence among team members.

Formative assessment. Pre-discussion formative assessments are crucial to ensuring accountability during the preparatory stages of the discussion leader role. Assessment occurs when the instructor reviews student drafts of questions, summaries, and answers in response to the article assigned for discussion. Although no formal grade is recorded, the student gains valuable individualized feedback. This private dialogue between instructor and student trains students to revise and reflect upon their work.

Summative assessment. Two forms of ongoing assessment take place while the instructor travels between discussion groups. First, students receive a weekly contributor grade that gauges their ability to demonstrate comprehension and engagement. The second form of summative assessment is a formal evaluation of the discussion leaders' in-class performance and revised homework that is submitted by way of the discussion folder. This allows for assessment of discussion leaders even when the instructor is not physically present for the entirety of the discussion period (see fig. 5). 


\section{INTRODUCTION TO WOMEN'S STUDIES DISCUSSION LEADER GRADING RUBRIC}

STUDENT

$/ 20$

$/ 20$

$/ 20$

$/ 20$

$/ 20$

$/ 100$

DATE

\section{QUESTION QUALITY}

Did the questions prompt meaningful discussion? Were the questions relevant? Were the questions easily understandable? Were the questions answerable? Did the questions highlight the main themes in the article? LEADERSHIP SKILLS

Did the discussion leader help facilitate the discussion? Did the leader maintain control of the discussion group? Did the leader ward off disrespectful behavior? Did the leader keep the group engaged?

TIME MANAGEMENT

Did the discussion last for the entire allotted time? Did the leader prevent the group from veering off topic? Did the discussion leader spend an adequate amount of time on each question?

\section{READING COMPREHENSION}

Could the leader discuss the article without re-reading the text? Was the leader able to answer questions about the article? Did the leader demonstrate comprehension of the main themes and arguments presented in the text? DISCUSSION PREPARATION

Did the discussion leader submit an electronic copy of her/his article summary and questions at least twenty four hours prior to the discussion period? Were there six questions? Did the discussion leader answer her/his own questions in extended prose? Was this work typed? Did the discussion leader submit a revised version of the questions and answers for grading?

Comments:

Figure 5. Discussion leader grading rubric.

Peer assessment. Discussion leaders face a considerable amount of performance pressure, and the outcomes of that work are partly dependent upon their classmates' willingness to engage. Discussion leaders use a quick peer-evaluation worksheet to report on their group's participation efforts (see fig. 6). Evidence exists that peer feedback enhances the internalization of quality standards (Falchikov, 2005); and although some scholars fear that peer assessment disrupts power relations in the classroom by undermining the authority of the instructor (Falchikoc, 2005), this technique will appeal to feminist teachers who dislike the dictatorship power-base of the traditional college lecturer. ${ }^{14}$

\footnotetext{
${ }^{14}$ Students do not determine their peers' final grades, but they do provide me with valuable data about what happened when I was not present.

Journal of the Scholarship of Teaching and Learning, Vol. 18, No. 2, June 2018.

josotl.indiana.edu
} 
Figure 6. Peer Evaluation Worksheet.

\section{INTRODUCTION TO WOMEN'S STUDIES PEER EVALUATION TO BE COMPLETED BY THE DISCUSSION LEADER}

DATE:

ASSIGNMENT DESCRIPTION: As the discussion leader, you will evaluate the contribution of your group members. These guidelines should help you complete this evaluation in a fair and meaningful manner. During discussion, everyone should participate by speaking, listening, thinking, and encouraging intellectual growth. The discussion team should share ideas, questions, and relevant examples. Students must limit their discussion to the assigned text and stay on task. Base each participant's evaluation score upon the quality of their contribution to the group discussion. Criteria for evaluation includes: evidence of preparation, providing relevant and insightful ideas and questions, encouraging others, listening attentively, and respecting others' discussion rights. Behavior that is damaging to discussions includes: evidence of poor preparation, dominating the conversation, repeatedly interrupting others, ignoring or withdrawing from the group, discouraging dissenting opinions, or other disrespectful behavior.

EVALUTION INSTRUCTIONS: After the discussion period ends, the following evaluation sheet should be completed by the discussion leader and placed in the back flap of the discussion folder. In the discussion performance box, place a check plus, check, check minus, or zero to indicate where each student belongs within the performance spectrum. Discussion leaders will not determine the grades of their peers, but these evaluations will help your professor determine each student's final discussion grade.

Excellent

Good

Fine

Poor

\begin{tabular}{|l|l|}
\hline \multicolumn{2}{|c|}{} \\
\hline 1. & Student Name \\
\hline 2. & \\
\hline 3. & \\
\hline 4. & \\
\hline 5. & \\
\hline 6. & \\
\hline 7. & \\
\hline
\end{tabular}

Comments:

Journal of the Scholarship of Teaching and Learning, Vol. 18, No. 2, June 2018.

josotl.indiana.edu 


\section{A Conversation Leads to Revision}

Is the four-folder system a superior instructional strategy? Quite honestly, that is not the question that this article intends to address, nor has the data collected thus far sought to provide a competitive or hierarchical perspective regarding feminist teaching methods. As Johnson-Bailey and Lee (2005) remind us, there is no universal way to approach feminist pedagogy, nor will all instructional methods work equally well for all professors. And it is at this point that I wish to reflect on a conversation that I had with a colleague from another institution who quickly pulled back when I described the four-folder approach. It was immediately clear to my colleague that my enthusiasm for improvisation and spontaneity was a manifestation of the privilege I enjoyed as a white female instructor in a predominantly white female classroom. Although my colleague applauded the results of my method, she disavowed any interest in experimenting with this strategy because for her, as a woman of color, it implied an unreasonable amount of personal risk. As Mingyeh Lee and Juanita Johnson-Bailey (2005) attest, “feminist pedagogy has encouraged teaching practices that empower students by asking teachers to develop styles that are non-authoritative and nurturing. However, we suggest that no one-size-fits-all feminist pedagogy exists, and that feminist pedagogy and women of color can make for a dangerous liason” (p.111). My colleague astutely confirmed that my course design did not adequately cope with the effects of my whiteness. Had I inadvertently recreated the same trappings as the "safe classroom" feminists who had come before?

Considering that white feminists often claim "safety" when they want to avoid the topic of race, (Ellsworth, 1989; Kishimoto \& Mwangi, 2009) alongside the fact that the vast majority of my students were white heterosexual women, we carried with us a considerable amount of privilege. In response to concerns raised by my colleague, I revised my course to better address lingering privilege (especially my own whiteness) by increasing the number of texts that dealt with race; referring to my own racial privilege; placing my "racialization" lectures earlier in the semester; spreading articles that engaged topics of racial identity, whiteness, and racism across the semester; and equally interrogating concepts of race in articles by white authors so that "everyone learns that affirmation of multiculturalism, and an unbiased inclusive perspective, can and should be present whether or not people of color are present” (hooks 2014). Further, emphasizing the experiences of non-western women of color presented opportunities for my students to grapple with perspectives that more adequately reflected the global majority. ${ }^{15}$ Apart from the actual content, I modified the structure of the course to include more online discussion boards through which students could engage in disembodied dialogues, and I made better use of the four-folder variations to offer minority students occasional breaks from predominantly white discussions. Merely remaining cognizant of the hazards of tokenism and hypervisibility of women of color in my overwhelmingly white class improved my choices in the selection and delivery of content.

It would be naïve to claim that these strategies undid white privilege, but they did have a positive impact. The degree to which the majority of my white students refuted the existence of white privilege lessened by midterm. These strategies may also have reduced the pressure felt by non-white students to comply with dominant white perspectives during discussions, though positionality makes this data more difficult to measure. I had not made their women's studies experience safer, but perhaps some students gained a better sense of belonging in this revised learning environment.

\footnotetext{
${ }^{15}$ For more on the benefits of globalizing with respects to teaching about race and class, see Hobson (2007). Journal of the Scholarship of Teaching and Learning, Vol. 18, No. 2, June 2018. josotl.indiana.edu
} 


\section{Evaluation of the Four-Folder System}

This study has used my teaching experience to examine the course design of a first-year undergraduate introductory women's studies course in the general education multicultural curriculum at a southern research university. The existence of unequal power in the classroom is not negated, but the small-group work and classroom community-making that develops over the course of the semester challenges (without fully dismantling) oppressive power relations through strategic separation, rotating leadership roles, and collaborative discussion periods that value the contribution of personal experiences, feelings, and ideas. The four-folder system might seem a return to traditional consciousness-raising strategies, but this would be an understatement. Unique advantages of the four-folder system include exploiting instructor surveillance by creating semiprivate problem-solving classroom spaces ${ }^{16}$ and exploiting power differentials by rotating the discussion wheel to modify the "margins" and "centers" of power in the room. This course design addresses the politics of the personal by valuing experiences among differently-situated women, but does not dispute that the activity places students in rhetorical danger of each other, and in proximity to what they originally perceived as the danger of feminism itself. By repeatedly simulating feminist debates, students make sense of the real world where safety may not be an option. To a certain degree, it is freedom from safety that enables this learning strategy to work. The cooperation and mutual benefit of the four-folder system achieves the "positive interdependence” described by Johnson, Johnson, and Smith (1991). From a feminist perspective, this model surpasses content mastery by straining towards the goal of training students to become self-directed learners who better understand themselves in relation to society. The following course evaluations from students in one of my fall 2011 classes evidences positive reception of the four folder system, and adds further support to studies (Springer, Stanne, \& Donovan, 1999; Pascarella \& Terenzini, 2005) that show structured group work to positively influence student motivation and learning.

"I thought the group discussions were extremely enlightening and useful. The groups allow students to create unions with other students and discuss the articles in a way that is more interactive than lecturing. In these groups I got to discuss the things which were unusual for typical teenage conversation but something I feel passionate about.”

"My professor... has a way of keeping control of the classroom and discussion while also allowing a time for students to express their views. I appreciate her trust in allowing us to break into discussion groups to talk about the readings.”

"I really enjoyed the groups. They helped me personally learn the concepts and it was useful since it helped build friendships that could be used in the class and outside of class. The groups made the discussion clearer since we had already been brainstorming about how to do things. I applaud the teacher in being brave enough to let us do this.”

Student evaluations across all sections of my women's studies classes suggested that my course design achieved many of its intended goals. Most students self-reported that they

\footnotetext{
${ }^{16}$ This model allows for varying degrees of surveillance that empowers students to selectively disclose personal information about themselves, and proved particularly useful for several students who were comfortable disclosing their sexuality to their peers, but did not immediately wish to share that information to me.

Journal of the Scholarship of Teaching and Learning, Vol. 18, No. 2, June 2018.

josotl.indiana.edu
} 
appreciated the course design, and many believed it enabled them to learn in a community environment. Their descriptions of the course align with Charlotte Bunch's (1983) vision of women's studies challenging students to become personally invested in the discipline. It may be possible for students to hide in a traditional seminar, but independent peer-led discussions thrust upon them an added responsibility for knowledge acquisition. My students frequently disclosed that they felt guilty if they were unable to answer their peers' questions. Peer-pressure (in the most positive sense) to take personal responsibility for group achievement intensified as the semester progressed, and even extended into other class assignments. This was true for students of all skill levels, including those who had completed prior women's studies classes.

"Coming into the class, I had received most of this information already due to another women's studies class and multiple sociology classes. So while the information was not new, it was presented in a different way or with different focus including going more in depth than I had previously done.” End-of-semester student reflection.

Student confessions such as these address my original breadth vs. depth dilemma and my personal crisis regarding the purpose of introductory women's studies seminars. Creating a multifocal discussion-based learning environment enabled me to essentially teach four small sections at once, each delving into different levels of depth to correspond with the group's needs.

An unanticipated effect of this course design was that student engagement greatly improved in my full-class discussions. Spillover moments such as these allow us to pinpoint the achievement of meta-objectives in the women's studies curriculum, as well as the successful integration of knowledge and skills across course components. As Barbara Millis (Active, 2010, p.5) argues, the type of “deep learning” that instructional methods like the four-folder system promote emerges from instructors who are committed to taking the time to design activities that push students in new and sometimes uncomfortable directions. These exercises move towards Michaelsen's (1992) concept of purposeful team leading, during which the majority of class time is devoted to a model in which the instructor acts as project facilitator while small group activities are repeatedly performed. The implied interactivity and interpersonal communication, shareddecision making, personal accountability, and conflict management skills demanded by the small group work in the four-folder system enhanced student learning.

\section{Final Thoughts on the Sound of Feminist Education}

Our folders are impeccably structured and ordered, a quilt of artifacts reflecting the time and effort of individual students and teams. It documents a sequence of lessons and files away a mélange of ideas that are representative of the class, and yet the knowledge produced by each discussion group is inescapably different. The most obvious and physically-measurable transformation that resulted from my implementation of the four-folder system was that my classes grew increasingly loud. Students acclimated to the volume of simultaneous and overlapping conversations that characterized our classroom soundscape, and which I interpret as sonic evidence of student engagement. Students may enter into my classroom with the same tasks to perform, but they leave with different conclusions. Thus is the inherently divergent nature of the feminist classroom, and the reason why the four-folder system succeeds. As I reflect on future implications, I recognize that this highly-structured collaborative learning model requires a great degree of organization, multi-tasking, time investment, subject competence, and instructional improvisation. It will not 
work equally well for everyone, but when the conditions described in this article manifest, benefits abound.

\section{My classes are loud \\ Enter the room \\ Hear how feminism sounds}

\section{References}

Amy, L.E. (2006). A pedagogy of witness: Encounter, crisis, and transformation in women's studies classes. Transformations: The Journal of Inclusive Scholarship and Pedagogy, 17(1), 5769.

Applebaum, B. (2014). Hold that thought! A response to "Respect differences? Challenging the common guidelines in social justice education.” Democracy \& Education, 22(2), 1-4.

Bunch, C. (1983). Not by degrees: Feminist theory and education. In Pollack, S., \& Bunch, C. (Eds.), Learning Our Way: Essays in Feminist Education (248-260). Trumansburg, NY: Crossing Press.

Brown, W. (1997). The impossibility of women's studies. differences: A Journal of Feminist Cultural Studies, 9(3), 79-101.

Crabtree, R.D., Sapp, D.A., \& Licona, A.C. (Eds). (2009). Feminist pedagogy: Looking back to move forward. Baltimore: Johns Hopkins University Press.

Culley, M. (1985). Anger and authority in the introductory women's studies classroom. In Culley, M., \& Portuges, C. (Eds.), Gendered Subjects: The Dynamics of Feminist Teaching (209217). Boston: Routledge, 209-217.

Ellsworth, E. (1989). Why doesn't this feel empowering? Working through the repressive myths of critical pedagogy. Harvard Educational Review, 59(3), 297-327.

https://doi.org/10.17763/haer.59.3.058342114k266250

Falchikov, N. (2005). Improving assessment through student involvement: Practical solutions for aiding learning in higher and further education. London: Routledge.

Fink, L.D. (2003). Creating significant learning experiences: An integrated approach to designing college courses. San Francisco: Jossey-Bass/Wiley.

Fisher, B.M. (2001). No angel in the classroom: Teaching through feminist discourse. Lanham, MD: Rowman \& Littlefield.

Freedman, E.B. (1990). Small group pedagogy: Consciousness raising in conservative times. NWSA Journal, 2(4), 603-623. 
Friedan, B. (1963). The feminine mystique. New York: Norton.

Hobson, J. (2007). The personal is global: Teaching global feminist consciousness. Transformations: The Journal of Inclusive Scholarship and Pedagogy 17(2), 96-105.

Hooks, B. (1989). Talking back: Thinking feminist, thinking black. Boston: South End. ---. (2003). Teaching community: A pedagogy of hope. New York: Routledge.

---. (2014). Teaching to transgress: Education as the practice of freedom. New York: Routledge.

Johnson, D.W., Johnson, R.T., \& Smith, K.A. (1991). Cooperative learning: Increasing college faculty instructional productivity. ASHE-ERIC Higher Education Report No. 4. Washington, DC: The George Washington University School of Education and Human Development. Retrieved May 25, 2018, from http://eric.ed.gov/?id=ED343465

Johnson-Bailey, J. (2003). Everyday perspectives on feminism: African American women speak out. Race, Gender \& Class 10(3), 82-99.

Johnson-Bailey, J., \& Ming-Yeh Lee. (2005). Women of color in the academy: Where's our authority in the classroom? Feminist Teacher, 15(2), 111-123.

Kishimoto, K., \& Mwangi, M. (2009). Critiquing the rhetoric of "safety" in feminist pedagogy: Women of color offering an account of ourselves. Feminist Teacher, 19(2), 87-102. https://doi.org/10.1353/ftr.0.0044

Lorde, A. (1984). Sister outsider: Essays and speeches. Trumansburg, NY: Crossing Press.

Ludlow, J. (2004). From safe space to contested space in the feminist classroom.

Transformations: The Journal of Inclusive Scholarship and Pedagogy, 15(1), 40-56.

Michaelsen, L. K. (1992). Team learning: A comprehensive approach for harnessing the power of small groups in higher education. In Wulff, D., \& Nyquist, J. D. (Eds), To Improve the Academy (107-122). Stillwater, OK: New Forums Press and the Professional and Organizational Development Network in Higher Education. Retrieved May 25, 2018, from http://digitalcommons.unl.edu/cgi/viewcontent.cgi?article=1248\&context=podimproveacad

Millis, B.J. (2010). Active learning strategies in face-to-face courses. IDEA Paper \#53. Manhattan, KS: The IDEA Center. Retrieved May 25, 2018, from http://ideaedu.org/wpcontent/uploads/2014/11/paperidea 53.pdf ---. (2002). Enhancing learning - and more! - through cooperative learning. IDEA Paper \#38. Manhattan, KS: The IDEA Center. Retrieved May 25, 2018, from http://ideaedu/org/wp-content/uploads/2014/11/IDEA Paper 38.pdf

Pascarella, E.T., \& Terenzini, P.T. (2005). How college affects students: A third decade of research. San Francisco: Jossey-Bass. 
Ray, N.M. (2010). Transforming teaching and learning: Teaching race. In Sheared, V., JohnsonBailey, J., Colin, III, S.A.J., Peterson, E., \& Brookfield, S.D. (Eds), The Handbook of Race and Adult Education: A Resource for Dialogue on Racism (71-82). San Francisco: Jossey-Bass.

Rich, A. (1979). Taking women students seriously. The Radical Teacher, 11, 40-43.

Sensoy, Ö., \& DiAngelo, R. (2014). Respect differences? Challenging the common guidelines in social justice education. Democracy and Education, 22(2), 1-10.

Shackelford, J. (1992). Feminist pedagogy: A means for bringing critical thinking and creativity to the economics classroom. Alternative Pedagogies and Economic Education, 82(2), 570-576.

Shrewsbury, C. (1987). What is feminist pedagogy? Women's Studies Quarterly, 15(3/4), 6-13.

Springer, L., Stanne, M.E., \& Donovan, S.S. (1999). Effects of small-group learning on undergraduates in science, mathematics, engineering, and technology: A meta-analysis. Review of Educational Research, 69(1), 21-51. https://doi.org/10.3102/00346543069001021

Tisdell, E.J. (1995). Creating inclusive learning environments for adults: Insights from multicultural education and feminist pedagogy. Information Series No. 361. Columbus, OH: ERIC Clearinghouse on Adult, Career, and Vocational Education. Retrieved May 25, 2018, from http://files.eric.ed.gov/fulltext/ED384827.pdf

Warren, L. (2000). Managing hot moments in the classroom. Cambridge: Harvard University Derek Bok Center for Teaching and Learning. Retrieved May 25, 2018, from http://isites.harvard.edu/fs/html/icb.topic58474/hotmoments.html

Weber Cannon, L. (1990). Fostering positive race, class, and gender dynamics in the classroom. Women's Studies Quarterly, 18(1/2), 126-134.

Winkler, B.S., \& DiPalma, C. (Eds). (1999). Teaching introduction to women's studies: Expectations and strategies. Westport, CT: Greenwood Publishing Group. 